\title{
The Role of Autoantibodies in Idiopathic Inflammatory Myopathies
}

\author{
In Seol Yoo, Jinhyun Kim \\ Department of Internal Medicine, Chungnam National University College of Medicine, Daejeon, Korea
}

\begin{abstract}
Idiopathic inflammatory myopathies (IIM) are a heterogeneous group of autoimmune muscle diseases with systemic involvement. Patients with IIM present with varying degrees of muscle disease, cutaneous manifestations, and internal organ involvement. The diagnosis and classification of IIM is based primarily on the classification system composed of clinical features, laboratory value and muscle biopsy. In addition, the identification and characterization of myositis-related autoantibodies can help diagnosis and classification. Recently, many studies have also demonstrated that the physician can define the clinical syndromes, establish treatment strategy and predict outcomes based on the patients' myositis-specific autoantibodies (MSA) and myositis-associated antibodies (MAA) profiles. MSAs are found exclusively in IIMs and facilitate the identification of subsets of patients with relatively homogeneous clinical features. MAAs are frequently found in association with other MSA; however, they may also be detected in various connective diseases. (J Rheum Dis 2019;26:165-178)
\end{abstract}

Key Words. Myositis, Dermatomyositis, Polymyositis, Antinuclear antibody

\section{INTRODUCTION}

Idiopathic inflammatory myopathies (IIM) are characterized by symmetric skeletal muscle weakness, neurophysiological or histological signs of muscle inflammation, elevated skeletal muscle enzymes, skin rashes and systemic organ involvement [1,2]. Based on the different clinical features and pathologic findings, they are classified into four subtypes: dermatomyositis (DM), polymyositis (PM), immune-mediated necrotizing myositis (IMNM), and inclusion-body myositis [3-9]. Due to this heterogeneity, patients with IIM can present with varying degrees of muscle disease, cutaneous manifestations and internal organ involvement [10-12].

The identification and characterization of autoantibodies (autoAbs) is quite helpful for the diagnosis and classification of systemic autoimmune diseases $[13,14]$. Recent reviews have discussed the clinical associations of myositis-related autoAbs, along with the clinical out- comes to develop appropriate management strategies [15-18]. More than 20-myositis-related autoAbs have been identified in patients with a range of clinical manifestations such as interstitial lung disease, cutaneous manifestations and cancer-associated myositis. This review highlights the current advances in autoAbs based on clinicopathological features, diagnostic utility and response to treatment.

\section{MAIN SUBJECTS}

\section{Definition of myositis-specific antibodies and myositis-associated antibodies}

Conventionally, myositis-related autoAbs have been classified into two categories: myositis-specific autoantibodies (MSAs) and myositis-associated autoantibodies (MAAs) [16-22]. MSAs show high specificity for IIM and are rarely found in other conditions except anti-aminoacyl transfer RNA (tRNA) synthetases (ARS). Anti-ARS

\footnotetext{
Received : March 6, 2019, Revised : March 20, 2019, Accepted : March 21, 2019

Corresponding to : Jinhyun Kim (iD http://orcid.org/0000-0001-5235-2612

Department of Internal Medicine, Chungnam National University College of Medicine, 266 Munhwa-ro, Jung-gu, Daejeon 35015, Korea. E-mail : jkim@cnuh.co.kr
}

Copyright (c) 2019 by The Korean College of Rheumatology. All rights reserved.

This is an Open Access article, which permits unrestricted non-commerical use, distribution, and reproduction in any medium, provided the original work is properly cited. 
In Seol Yoo and Jinhyun Kim

Table 1. Target autoantigens and prevalence of myositis specific antibodies

\begin{tabular}{|c|c|c|c|c|c|c|c|c|}
\hline \multirow{2}{*}{ Antibody } & \multirow{2}{*}{ Antigen } & \multirow{2}{*}{ Antigen function } & \multirow{2}{*}{$\begin{array}{l}\text { Protein } \\
\text { (kDa) }\end{array}$} & \multicolumn{5}{|c|}{ Prevalence in IIM (\%) } \\
\hline & & & & DM & PM & OVM & CAM & JDM \\
\hline Anti-ARS & & & & 20 & 29 & 13 & 13 & $1 \sim 3$ \\
\hline Anti-Jo-1 & $\begin{array}{l}\text { Histidyl tRNA } \\
\text { synthetase }\end{array}$ & $\begin{array}{l}\text { Incorporate histidine into } \\
\text { proteins }\end{array}$ & 50 & 11 & 21 & 4 & 7 & \\
\hline Anti-PL-7 & $\begin{array}{l}\text { Threonyl tRNA } \\
\text { synthetase }\end{array}$ & $\begin{array}{l}\text { Incorporate threonine into } \\
\text { proteins }\end{array}$ & 80 & & & & & \\
\hline Anti-PL-12 & $\begin{array}{l}\text { Alanyl tRNA } \\
\text { synthetase }\end{array}$ & $\begin{array}{l}\text { Alanine and aspartate } \\
\text { biosynthesis and alanine } \\
\text { incorporation into proteins }\end{array}$ & 110 & & & & & \\
\hline Anti-EJ & $\begin{array}{l}\text { Glycyl tRNA } \\
\text { synthetase }\end{array}$ & $\begin{array}{l}\text { Glycine, serine and threonine } \\
\text { metabolism, and aminoacyl } \\
\text { tRNA biosynthesis }\end{array}$ & 75 & & & & & \\
\hline Anti-OJ & $\begin{array}{l}\text { Isoleucyl tRNA } \\
\text { synthetase }\end{array}$ & $\begin{array}{l}\text { Incorporate isoleucine } \\
\text { into proteins }\end{array}$ & $\begin{array}{c}150+70 / \\
130 / 75\end{array}$ & & & & & \\
\hline Anti-KS & $\begin{array}{l}\text { Asparaginyl tRNA } \\
\text { synthetase }\end{array}$ & $\begin{array}{l}\text { Glutamate, alanine and } \\
\text { aspartate metabolism }\end{array}$ & 65 & & & & & \\
\hline Anti-Zo & $\begin{array}{l}\text { Phenylalanyl tRNA } \\
\text { synthetase }\end{array}$ & $\begin{array}{l}\text { Incorporate phenylalanine into } \\
\text { proteins }\end{array}$ & $60 / 70$ & & & & & \\
\hline Anti-YRS/HA & $\begin{array}{l}\text { Tyrosyl tRNA } \\
\text { synthetase }\end{array}$ & $\begin{array}{l}\text { Incorporate tyrosine } \\
\text { into proteins }\end{array}$ & 59 & & & & & \\
\hline Anti-Mi-2 & $\begin{array}{l}\text { Nucleosome } \\
\text { remodelling } \\
\text { Deacetylase (NuRD) } \\
(\mathrm{Mi}-2 \alpha / \beta)\end{array}$ & Transcription regulation & $\begin{array}{l}240+200 / \\
150 / 75 / 65 / \\
63 / 50 / 34\end{array}$ & 9 & 1 & 8 & 9 & $<10$ \\
\hline Anti-SAE & $\begin{array}{l}\text { Small ubiquitin-like } \\
\text { modifier } 1 \text { activating } \\
\text { enzyme (SAE1/2) }\end{array}$ & $\begin{array}{l}\text { Post-translational protein } \\
\text { modification }\end{array}$ & $40 / 90$ & & Adult: & $3 \sim 5$ & & 1 \\
\hline $\begin{array}{l}\text { Anti-MDA5 } \\
\text { (anti-CADM140) }\end{array}$ & $\begin{array}{l}\text { Melanoma } \\
\text { differentiation- } \\
\text { associated gene } \\
5 \text { (MDA5) }\end{array}$ & $\begin{array}{l}\text { Recognizes the viral RNAs } \\
\text { and initiate signaling events } \\
\text { leading to type I interferon } \\
\text { production }\end{array}$ & 140 & & Adult: & $1 \sim 30$ & & 7 \\
\hline $\begin{array}{l}\text { Anti-TIF1 } \gamma / \alpha \\
(\text { (anti-p155/p140) }\end{array}$ & $\begin{array}{l}\text { Transcription } \\
\text { intermediary factor } \\
1(\operatorname{TIF} 1 \gamma / \alpha)\end{array}$ & $\begin{array}{l}\text { Regulation of transcription, } \\
\text { tumor suppression, DNA } \\
\text { damage repair and } \\
\text { modulation } \\
\text { of TGF- } \beta \text { signaling }\end{array}$ & $155 / 140$ & & Adult: & & & $18 \sim 30$ \\
\hline Anti-NXP-2 (anti-MJ) & $\begin{array}{l}\text { Nuclear matrix } \\
\text { protein } 2\end{array}$ & $\begin{array}{l}\text { Transcription regulation and } \\
\text { p53 activation }\end{array}$ & 140 & & Adult: & $2 \sim 17$ & & $15 \sim 20$ \\
\hline Anti-SRP & $\begin{array}{l}\text { Signal recognition } \\
\text { particle }\end{array}$ & $\begin{array}{l}\text { Regulate the recognition and } \\
\text { translocation of proteins } \\
\text { across the endoplasmic } \\
\text { reticulum }\end{array}$ & $\begin{array}{c}72 / 68 / 54 / \\
19 / 14 / 9\end{array}$ & 1 & 5 & 5 & 11 & $<1$ \\
\hline Anti-HMGCR & $\begin{array}{l}\text { HMG-CoA } \\
\text { reductase }\end{array}$ & $\begin{array}{l}\text { Rate-limiting enzyme of } \\
\text { cholesterol synthesis }\end{array}$ & $200 / 100$ & & Adult: & & & 1 \\
\hline
\end{tabular}

IIM: idiopathic inflammatory myopathies, DM: dermatomyositis, PM: polymyositis, OVM: overlap myositis, CAM: cancer associated myositis, JDM: juvenile myositis, ARS: aminoacyl transfer RNA (tRNA) synthetases, Jo-1: histidyl, PL-7: threonyl, PL-12: alanyl, EJ: glycyl, OJ: isoleucyl, KS: asparaginyl, Zo: phenylalanyl, YRS/HA: tyrosyl, SAE: small ubiquitin-like modifier activating enzyme, MDA5: melanoma differentiated-associated protein 5, CADM: clinically amyopathic dermatomyositis, TIF1: transcription intermediary factor 1, NXP: nuclear matrix protein, SRP: signal recognition particle, HMGCR: 3-hydroxy-3-methylglutaryl CoA reductase, NuRD: nucleosome remodeling deacetylase, TGF: transforming growth factor. 
antibodies, especially anti-PL-7, PL-12 and KS, are found in patients with idiopathic interstitial lung disease (ILD), independent of muscular involvement [23-25]. MAAs are associated with myositis; however, they are also found in other related conditions including systemic sclerosis (SSc) and systemic lupus erythematosus (SLE). A few MAAs, such as anti-PM-Scl, U1/U2 ribonucleoprotein (RNP) and $\mathrm{Ku}$ are associated with overlap syndromes with muscular involvement [26]. Anti-Ro52 is usually classified as MAA. It is frequently detected in patients with MSAs such as anti-ARS, anti-melanoma differentiated-associated protein 5 (MDA5) and anti-signal recognition particle (SRP), and also frequently in patients with SLE, SSc, Sjögren syndrome, and other diseases [27].

\section{Myositis-specific autoantibodies}

MSA are found in IIMs exclusively and facilitate the identification of subsets of patients with relatively homogeneous clinical features. MSAs are summarized in Table 1.

\section{1) Anti-ARS antibodies}

Anti-ARS are a group of autoAbs directed against the aminoacyl tRNA synthetases. Currently, autoantibodies that recognize eight ARSs have been described as follows: histidyl (Jo-1), threonyl (PL-7), alanyl (PL-12), glycyl (EJ), isoleucyl (OJ), asparaginyl (KS), phenylalanyl (Zo), and tyrosyl (YRS/HA) tRNA synthetases $[28,29]$. They are associated with anti-synthase syndrome characterized by myositis, interstitial lung disease, non-erosive arthritis, Raynaud's phenomenon, fever, and mechanic's hands [30,31].

Anti-Jo-1 has been identified in 15\% 25\% of patients with PM/DM and overlap syndrome, but not in SLE, SSc, or other diseases $[16,28]$. Other ARS antibodies, such as anti-PL-7, anti-PL-12, anti-EJ, anti-OJ, anti-Ha, anti-KS and anti-Zo antibodies, are usually found only in $0.5 \%$ $6 \%$ of patients of IIM [17,22,32-34]. Regardless of race, ethnicity, or nationality, the reported frequency of various anti-ARS is very similar [17,22,32-34], except for the high frequency of anti-PL-12 antibodies detected in southern USA [35] and the high prevalence of anti-PL-7 in a Japanese cohort [36].

Several studies have reported differences in clinical manifestations depending on the types of anti-ARS. Muscle involvement and arthritis are common in patients carrying anti-Jo-1, whereas anti-PL-7 positive patients usually manifest milder muscular involvement [36]. The presence of anti-PL-7, anti-KS, anti-OJ or anti-PL-12 antibodies is associated with a higher prevalence of severe ILD [35-41]. In this group, usual interstitial pneumonia and acute interstitial pneumonia are usually detected early in disease [15,39-44]. A few studies suggested that anti-PL-12 and anti-KS are common in ILD without myositis $[23,24,35]$. In a recent study of 31 patients testing positive for anti-PL-12, a strong association with ILD was found but limited association with myositis and arthritis [45].

Compared with adults, juvenile dermatomyositis (JDM) is rarely associated with anti-ARS antibodies. Rider et al. [46] investigated the sera from 77 children with myositis and overlap connective tissue disease, and anti-ARS antibodies were detected in only $2.6 \%$ cases. Even in the studies reported by Feldman et al. [47] and Wedderburn et al. [48], no patient with positive anti-ARS antibodies was found [49].

\section{2) Anti-Mi-2 antibodies}

Anti-Mi-2 autoAbs were first reported as MSA in DM in 1985 [50,51]. Mi-2 antigen is a helicase belonging to the nucleosome remodeling deacetylase multi-protein complex with nucleosome remodeling and histone deacetylase/demethylase activities [16,52]. Although anti-Mi-2 immunoprecipitates this entire complex, including Mi-2 protein, histone deacetylases, histone binding proteins, and others, the $240 \mathrm{kDa} \mathrm{Mi}-2$ protein is the major antigen composed of two proteins, Mi- $2 \alpha$ and Mi- $2 \beta[53,54]$.

The prevalence of anti-Mi-2 ranges from $2 \%$ to $38 \%$ within adult DM populations and $4 \%$ to $10 \%$ within JDM populations $[20,50,51]$. These differences of prevalence are mainly attributed to differences in countries and races; however, they often differ between studies conducted in the same country $[15,55]$. The prevalence of anti-Mi- 2 in adults varies from $5 \%$ to $27 \%$ in Italy and $2 \%$ to $19 \%$ in Japan [15]. Two studies reported very high prevalence of anti-Mi-2 in a majority of countries in Central and South America [55,56]. The prevalence was as low as $3.2 \%$ in Montreal (Canada), compared with $60 \%$ in Guatemala City (Guatemala), $36.1 \%$ in Mexico City (Mexico), and 23.1\% in Santiago (Chile) [56]. These geographical variations of anti-Mi-2 positivity suggest that ultraviolet (UV) irradiation may influence the development of anti-Mi-2 and DM [56,57]. However, Petri et al. [55] showed a 59\% prevalence of anti-Mi-2 among DM patients living in Mexico City, whereas it was only $12 \%$ in Guadalajara, suggesting that UV exposure was not the 
only risk factor for the development of anti-Mi-2 autoAbs. A few studies reported the association between human leukocyte antigen (HLA) alleles and anti-Mi-2. HLADRB $1{ }^{*} 0302$ was identified as the primary allelic risk factor among African Americans and HLA-DRB1*0701/ DQA $1 * 0201$ as the primary allelic risk factor among European Americans [58-60].

Anti-Mi-2 is myositis-specific; it is usually associated with DM rather than PM [20]. It is associated with the classic features of DM including Gottron's papules, heliotrope rash, shawl sign, and V-sign, high creatine kinase (CK) levels, without lung involvement or cancer $[15,20,50]$. Anti-Mi-2-positive patients respond well to corticosteroid therapy with favorable outcomes $[20,61,62]$. More recently, rituximab therapy resulted in favorable treatment outcomes in anti-Mi-2 autoantibody-positive patients $[63,64]$.

\section{3) Anti-SAE antibodies}

Anti-SAE autoAb targets the A and B subunits of small ubiquitin-like modifier 1 (SUMO-1) activating enzyme and were first identified in DM patients in 2007 [65]. SUMOs play a key role in post-transcriptional modification of specific proteins similar to ubiquitination. This process is controlled by the SUMO-Activating Enzyme (SAE), a heterodimer composed of two subunits, SAE-1 (40 kDa) and SAE-2 (90 kDa), representing the targets of anti-SAE [66]. The prevalence of anti-SAE1/2 autoAbs varies from $1 \%$ to $3 \%$ in Asian populations and $5 \%$ to $10 \%$ in European populations [66-71].

The cutaneous involvement of anti-SAE positive patients is usually severe and typically precedes muscular involvement, while another subset presented with skin and muscle disease simultaneously [66-69,71]. Dysphagia was noted in a majority of patients and was significantly more common in a Chinese study [69-71]. ILD in anti-SAE1/2-positive patients is usually mild and rare, except Japanese [69,71]. Also, patients diagnosed with pulmonary arterial hypertension were identified in Chinese and Japanese studies $[69,70]$.

\section{4) Anti-MDA5 antibodies}

AutoAbs to MDA5 were first described by Sato et al. [72]. Anti-MDA5 autoAbs were initially designated as anti-CADM-140, because they were detected in immunoprecipitation as a $140 \mathrm{kDa}$ band among patients with clinically amyopathic dermatomyositis (CADM) and rapidly progressive interstitial lung disease (RP-ILD)
[72]. MDA5 encodes a cytosolic double-stranded RNA sensor, which is a member of the family of retinoic acid-inducible gene I-like receptors, and it recognizes the viral RNAs and initiates signaling events leading to type I interferon production [73].

Anti-MDA5s are more prevalent in Asian (11\% 57\%) than in Caucasian populations (0\% 13\%) [51,61,73-77]. The HLA-DRB1*0401 and DRB1*1202 alleles in Japanese patients and the DRB1*1201 allele in Chinese patients are associated with anti-MDA5 [78,79]. Also, the DRB ${ }^{*} 0901$ is identified as a poor prognostic factor in anti-MDA5-positive patients [79].

A meta-analysis demonstrated that the anti-MDA5 autoAbs are significantly associated with DM-ILD in both Asian and Caucasian patients (odds ratio [OR], 16.47) $[51,80]$. The RP-ILD is associated with high mortality and poor prognosis in anti-MDA5 patients [51,81].

Numerous studies have reported the unique clinical features of anti-MDA5-positive patients. The cutaneous phenotype is often particularly severe in anti-MDA5 patients. Cutaneous manifestations include alopecia, tender papules or macules on the palmar surfaces of the metacarpophalangeal and interphalangeal joints known as 'inverse Gottron's papules', cutaneous ulcers and oral erosions [18,50,61,76,77]. Wolstencroft et al. [82] recently suggested that clinical remission of skin disease is less likely in the anti-MDA5-positive group. A high prevalence of inflammatory arthritis among antiMDA5-positive patients has been reported in numerous studies [73,76,83]. Anti-MDA5-positive DM patients have been misdiagnosed with psoriatic or rheumatoid arthritis due to symmetric polyarthritis [76,84]. Particularly, high ferritin levels above $1,500 \mathrm{ng} / \mathrm{mL}$ are associated with poor prognosis $[85,86]$. A large number of antiMDA5-positive patients (35\% 74\%) present fever compared with anti-MDA5-negative patients $[51,87,88]$.

The anti-MDA5 antibody titer appears to reflect disease activity and response to therapy. Muro et al. [89] demonstrated that anti-MDA5 antibody decreased to negative levels in nine of 10 patients tested with ELISA during the remission after treatment. Among the 10 patients diagnosed with DM and RP-ILD, the mean anti-MDA5 titer before treatment was significantly lower in patients who responded to therapy and survived than in those who failed to respond, resulting in death [90].

\section{5) Anti-TIF1 antibodies}

About $20 \%$ of adults diagnosed with DM were related to 
malignancies [91]. Several factors, such as male gender, old age, and severe skin lesions were positively associated with cancer [91]. Further, autoAbs to transcription intermediary factor 1 (TIF1) are associated with cancer in DM. In 2006, Targoff et al. [92] and Kaji et al. [93] independently identified two antibodies directed against 155 (TIF1 $\gamma$ ) and 140 (TIF1 $\alpha$ ) kDa proteins. In addition, a third $120 \mathrm{kDa}$ protein was identified as TIF1 $\beta$ [94-96]. TIF1 $\alpha$, TIF $1 \beta$, and TIF1 $\gamma$ belong to the tripartite motif-containing protein (TRIM) superfamily (TRIM24, TRIM28, and TRIM33, respectively) involved in cell cycle regulation, mitosis and innate immunity [91]. Based on the two studies, TIF $1 \gamma$ played an important role in the regulation of transcription, tumor suppression, DNA damage repair, and modulation of transforming growth factor- $\beta$ signaling [96,97].

Anti-TIF1 $\gamma$ autoAbs are more prevalent in Caucasian $(38 \% \sim 41 \%)$ than in Asian populations (7\% 21\%) [61,94,98-101]. The risk of malignancy was significantly higher in adult patients carrying both anti-TIF1 $\alpha$ and anti-TIF1 $\gamma$ antibodies than in those with anti-TIF1 $\gamma$ antibodies alone ( $73 \%$ vs. $50 \%$; $\mathrm{p}<0.05)$ [95]. The prevalence of anti-TIF $1 \gamma / \alpha$ in cancer-associated DM varied from $22 \%$ to $100 \%$ [15]. The prevalence of malignancy in anti-TIF $1 \gamma / \alpha$ antibody-positive patients ranges from $42 \%$ to $100 \%$ [15]. A meta-analysis showed that the pooled sensitivity of anti-TIF1 $\gamma$ for the diagnosis of cancer-associated DM was $78 \%$ (95\% confidence interval [CI], 45\% 94\%), and the specificity was $89 \%$ (95\% CI, $82 \% \sim 93 \%$ ) [102]. Solid cancers, such as those associated with ovary, lung and breast as well as hematologic malignancies are associated with anti-TIF1 $\gamma$ positivity [16].

Patients with anti-TIF1 $\gamma / \alpha$ antibody manifest classic skin lesions (heliotrope rash, Gottron's papules, V-sign, and shawl sign) and rarely develop Raynaud's disease, arthralgia, or ILD [93,99].

\section{6) Anti-NXP-2 antibodies}

The autoAb to nuclear matrix protein (NXP-2 or MORC3) was found in a cohort of JDM patients, initially designated as anti-MJ [103]. NXP-2 is a $140 \mathrm{kDa}$ protein, which plays an important role in epigenetic regulation, RNA metabolism, and preservation of nuclear chromatin architecture [103,104].

The prevalence of anti-NXP-2 in adult DM varies from $1.6 \%$ to $17 \%$ [105-107]. Ichimura et al. [105] reported a $1.6 \%(8 / 507)$ prevalence of anti-NXP-2 in a Japanese co- hort, and four of eight patients were associated with malignancy. In the first study of anti-NXP-2 involving adult DM conducted in UK, the prevalence was 3\% (11/393) in PM/DM, 6\% in DM, and none in PM [106]. The typical signs of DM rash and ILD were more common in anti-NXP-2 positive patients. Another study involving adult patients with DM in USA reported anti-NXP-2 antibodies in $13 \%(16 / 126)$ of cases, associated with calcinosis (OR, 15.52) [107]. In an Italian study, the prevalence of anti-NXP-2 was $30 \%$ in DM and $17 \%$ in PM/DM [108], which was higher than in any other adult DM studies. Also, no case of malignancy was detected in the Italian cohort; however, it appeared to be related with young age compared with malignancies involving other cohorts $[15,100]$.

A few studies of anti-NXP-2 positivity in JDM patients have been reported [109-111]. Oddis et al. [109] first described the anti-NXP-2 antibodies in 1997. The JDM patients carrying anti-NXP-2 were characterized by severe refractory DM associated with polyarthritis, joint contractures, severe calcinosis, and intestinal vasculitis [109]. In an Argentinian cohort of pediatric myositis, 16 (25\%) patients had anti-NXP-2 autoAbs, which were diagnostic of a subset of patients with severe pediatric myositis characterized by muscle contractures and atrophy, and significant functional impairment [110]. In the UK/Ireland study, 37 (23\%) of 162 patients with JDM tested positive for anti-NXP-2 autoAbs and were associated with a significantly higher prevalence of calcinosis (54\% vs. $15 \%$ in anti-NXP-2 negative patients) [111].

Based on numerous studies, the anti-NXP-2 positive patients, especially males, carried a high risk of cancer $[100,105,112,113]$. Fiorentino et al. [100] reported that anti-NXP-2 was specifically associated with cancer in males (OR, 5.78; 95\% CI, 1.35 24.7). In addition to cancer, the anti-NXP-2 positive patients exhibited unique clinical features, such as frequent and severe muscle weakness, myalgia, dysphagia, and peripheral edema $[105,112,113]$. Also, calcinosis cutis was a distinguishing feature of anti-NXP-2 in both adult DM and JDM patients [107-109,111-113].

\section{7) Anti-SRP antibodies}

The autoAbs to SRP were originally detected in a patient diagnosed with PM [114]. SRP is a complex of six proteins $(9,14,19,54,68$ and $72 \mathrm{kDa})$ and a 7SL RNA, which regulate protein recognition and translocation across the endoplasmic reticulum. Anti-SRPs are more frequently 
bound to the $54 \mathrm{kDa}$ subunit of the SRP than the others [114].

The anti-SRPs are found in $4 \%$ to $6 \%$ of patients with IIM, and a majority of them were thought to be associated with PM [115-119]. After IMNM was identified as a new subtype of IIM distinctive from PM, it was revealed that the anti-SRP antibodies was are strongly associated with IMNM, which is characterized by scarce inflammatory CD8+ endomysial mononuclear cell infiltrate, class I MHC up-regulation, necrosis and myofiber regeneration with poor response to therapy, mimicking muscular dystrophy $[16,120,121]$. Prevalence of IMNM in patients with anti-SRP antibodies ranges from $0 \%$ to $54 \%$ [122-125].

Anti-SRP-positive patients generally present with acute or subacute onset severe myopathy with high CK levels (often 10-fold higher than the upper limit of normal) and dysphagia caused by esophageal involvement [115-118]. A number of studies have described ILD and cardiac involvement, which has yet to be corroborated $[115,117,126]$. Remarkably, a striking correlation was observed between the degree of myositis based on the CK levels and the anti-SRP levels in patients receiving therapy [127].

\section{8) Anti-HMGCR antibodies}

The 3-hydroxy-3-methylglutaryl CoA reductase (HMGCR) is the second autoantigen identified in IMNM $[128,129]$. HMGCR is the rate-limiting enzyme of the mevalonate pathway, which is essential for cholesterol synthesis [130]. The skeletal muscle-specific HMGCR-knockout mice exhibited postnatal myopathy with elevated serum CK levels and necrosis. Myopathy in knockout mice was completely rescued by the oral administration of mevalonate [131].

The anti-HMGCR antibodies were strongly associated with statin exposure and HLA-DRB1*11. The highest risk for the development of anti-HMGCR antibodies was observed among HLA-DR11 carriers exposed to statins $[132,133]$. A history of statin use is not essential to develop anti-HMGCR positive IMNM. Only $40 \%$ to $60 \%$ of patients with anti-HMGCR-positive IMNM with reported prior statin use [134-136]. Nevertheless, $76.5 \%$ to $92 \%$ of patients aged 50 and older were exposed to statins. The anti-HMGCR antibodies have been detected in $4 \%$ to $6 \%$ of patients in American and European cohorts $[134,136]$. Among the patients with IMNM, anti-HMGCR antibodies have been detected among nearly $62 \%$ [130].
The anti-HMGCR levels are correlated with CK levels and represent disease activity in IMNM [137,138]. Extramuscular manifestations such as skin involvement and ILD are relatively rare $[137,138]$. Severe limb muscle weakness, neck weakness, dysphagia, respiratory insufficiency and muscle atrophy were more frequently observed in patients carrying anti-SRP antibodies than in those with anti-HMGCR antibodies [139]. Importantly, the anti-HMGCR-positive IMNM patients carried a modestly increased risk of malignancy (standardized incidence ratio, 2.79) [140].

Anti-HMGCR-positive patients with IMNM require treatment with steroids and other immunosuppressive therapies to control the disease $[135,138]$. The combination of intravenous immunoglobulin (IVIG) and oral immunosuppressive agents or IVIG monotherapy may be an effective therapeutic approach to achieve remission $[135,138,141]$. Younger anti-HMGCR-positive patients manifest more severe disease, and may develop progressive and permanent weakness [142,143].

\section{Myositis-associated autoantibodies}

MAA are frequently found in association with other MSA (ARS, anti-MDA5 and anti-SRP, in particular); however, they also can be detected in various connective diseases. MAA are summarized in Table 2.

\section{1) Anti-PM-Scl antibodies}

The PM-Scl autoantigen was first identified in 1977 in the sera of patients diagnosed with PM [144]. In 1984, Reichlin et al. [145] and Treadwell et al. [146] reported that anti-PM-Scl were most prevalent in patients with PM-SSc overlap syndrome.

Anti-PM-Scl autoAbs are directed against a nucleolar macromolecular complex composed of 11 to 16 proteins (ranging from 20 to $110 \mathrm{kDa}$ ). The two key proteins of the complex are PMScl-75 (75 kDa) and PM-Scl-100 (100 $\mathrm{kDa}$ ) with PMScl-75 considered as the main autoantigen. This macromolecular complex is the human counterpart of the yeast exosome, which is involved in RNA degradation and processing [147-149]. According to a recent meta-analysis, the anti-PM-Scl antibodies have been detected in $17 \%$ of patients diagnosed with PM/SSc overlap syndrome, compared with only $6 \%$ of patients with PM alone and $9 \%$ of patients with DM alone [150]. Also, the frequency of anti-PM/Scl antibodies appears to vary between different ethnic groups. Brouwer et al. [151] reported that anti-PM-Scl antibodies were more often de- 
Table 2. Target autoantigens and prevalence of myositis associated antibodies

\begin{tabular}{|c|c|c|c|c|c|c|c|c|}
\hline \multirow{2}{*}{ Antibody } & \multirow{2}{*}{ Antigen } & \multirow{2}{*}{ Antigen function } & \multicolumn{5}{|c|}{ Prevalence in IIM (\%) } & \multirow{2}{*}{ Clinical association } \\
\hline & & & DM & PM & OVM & CAM & JDM & \\
\hline Anti-PM-Scl & $\begin{array}{l}\text { Exosome (PMScl) complex; } \\
\text { PMScl-75 (75 kDa)/PMScl- } \\
100(100 \mathrm{kDa})\end{array}$ & RNA degradation & 9 & 6 & 17 & 0 & 5 & $\begin{array}{l}\text { PM/SSc overlap } \\
\text { syndrome } \\
\text { classically SSc }\end{array}$ \\
\hline Anti-U1-RNP & Small ribonucleoprotein & Splicing of mRNA & 6 & 5 & 32 & 0 & 5 & $\begin{array}{l}\text { PM/SSc overlap } \\
\text { syndrome } \\
\text { MCTD }\end{array}$ \\
\hline Anti-Ro52 & Ro52/TRIM21 & $\begin{array}{l}\text { Mediates proteasome- } \\
\text { related degradation of } \\
\text { target proteins }\end{array}$ & 13 & 12 & 19 & 0 & 6 & $\begin{array}{l}\text { ILD } \\
\text { Frequently } \\
\text { associated with MSA }\end{array}$ \\
\hline Anti-Ku & $\begin{array}{l}\text { DNA-binding protein } \\
\text { consisting of } 70 \text { and } \\
80 \text { kDa subunits }\end{array}$ & $\begin{array}{l}\text { DNA repair through the } \\
\text { non-homologous } \\
\text { end-joining pathway }\end{array}$ & 1 & 2 & 13 & 0 & $<1$ & $\begin{array}{l}\text { PM/SSc overlap } \\
\text { syndrome }\end{array}$ \\
\hline
\end{tabular}

IIM: idiopathic inflammatory myopathies, DM: dermatomyositis, PM: polymyositis, OVM: overlap myositis, CAM: cancer associated myositis, JDM: juvenile myositis, SSc: systemic sclerosis, MCTD: mixed connective tissue disease, ILD: interstitial lung diseas, MSA: myositis-specific autoantibodies, RNP: ribonucleoprotein.

tected in European patients than in North American and Japanese groups ( $6 \%$ vs. $2 \%$ vs. $0 \%$ ). On the other hand, they were not detected in a large series of 275 Japanese patients with SSc [152]. Patients diagnosed with anti-PM/Scl-positive PM/SSc overlap syndrome frequently presented with Raynaud's phenomenon, arthritis, mechanic's hands and ILD [150,153]. The PM/SSc overlap syndrome appeared to show a benign and chronic disease course, and the anti-PM/Scl antibodies have been shown to predict limited cutaneous involvement [154]. Also, the anti-PM/Scl-positive patients responded favorably to low-to-moderate doses of corticosteroids [154-156].

\section{2) Anti-U1-RNP antibodies}

Anti-RNP were first observed in SLE patients with speckled IIF pattern in 1971 [157]. The RNP/Sm complex consists of several proteins $\left(70 \mathrm{kDa}, \mathrm{A}, \mathrm{A}^{\prime}, \mathrm{B}, \mathrm{B}^{\prime}, \mathrm{B}^{\prime \prime}\right.$, C, D, E, F, G) constituting the common core of U1, U2, U4 and U5 small nuclear ribonucleoprotein (snRNP) particles $[158,159]$. The anti-RNP antibodies react with U-rich $70 \mathrm{kDa}(\mathrm{U1}), 33 \mathrm{kDa}(\mathrm{A})$ and $22 \mathrm{kDa}(\mathrm{C})$ proteins that are associated with U1 RNA and form U1snRNP $[158,159]$. However, only the elevated $70 \mathrm{k}$ anti-U1-RNP titers are considered specific markers of mixed connective tissue disease [158].

Anti-U1-RNP antibodies have been found in $32 \%$ of patients diagnosed with overlap myositis, compared with only $5 \%$ of patients with PM alone and $6 \%$ of patients with DM alone [150]. The patients with anti-U1-RNP positive myositis usually manifest a mild disease course and respond well to corticosteroids $[160,161]$.

\section{3) Anti-Ro52 antibodies}

The Ro/La system is composed of three different proteins (52 kDa Ro, $60 \mathrm{kDa}$ Ro, and $48 \mathrm{kDa} \mathrm{La}$ ) and four small RNA particles (hY1, hY3, hY4, and hY5-RNA) [162]. The Ro/SSA autoantibody-system (Ro60 and Ro52) is the most prevalent nuclear antigen specifically identified in autoimmune diseases, such as SLE, overlap syndrome, subacute cutaneous LE, neonatal lupus and primary biliary cirrhosis with similar prevalence $[162,163]$. Notably, anti-Ro52 is detected more frequently in myositis $(35.4 \%$ vs. $0.0 \%, \mathrm{p}<0.001)$ and SSc $(19.0 \%$ vs. $6.0 \%, \mathrm{p}<0.005)$ than anti-Ro60 [163]. In IIM, anti-Ro52 autoAbs are frequently associated with MSAs. Yamasaki et al. [164] reported that anti-Ro52 antibodies were frequently detected with anti-ARS (59\%) (57\% in anti-Jo- 1 and $67 \%$ in anti-PL-7) (vs. $21 \%$ in anti-ARS-negative, $\mathrm{p}<0.0002)$ in a Japanese IIM cohort. In this study, anti-Ro52 was also associated with overlap syndrome (26\%) (vs. $7 \%$ in anti-Ro52-negative, $\mathrm{p}=0.0119$ ). Furthermore, compared with IIM patients testing negative for anti-Jo-1-positive/anti-Ro52, the anti-Jo-1/anti-Ro52-positive IIM patients more commonly manifested severe myositis, joint involvement, ILD, and cancer with poor prognosis [165]. Also, anti-Ro52s are associated with anti-MDA5 [67] and anti-SRP [166]. 


\section{4) Anti-Ku antibodies}

In 1981, anti-Ku antibodies were originally linked to $\mathrm{PM} / \mathrm{SSc}$ overlap syndrome by Mimori et al. [167]. $\mathrm{Ku}$ is a DNA-binding protein consisting of 70 and $80 \mathrm{kDa}$ subunits involved in DNA repair via the non-homologous end-joining pathway [168].

According to a recent meta-analysis, the anti-Ku antibodies have been found in $13 \%$ of patients diagnosed with PM/SSc overlap syndrome, compared with only $2 \%$ of patients with PM alone and $1 \%$ of patients with DM alone [150]. Anti-Ku antibodies are not associated with specific clinical manifestations such as cancer-associated myositis. Interestingly, the anti-Ku positive patients respond well to treatment and appear to show a favorable prognosis [168].

\section{Prevalence of MSA and MAA in Korea}

There are only a few reports about the prevalence of MSA and MAA in Korean patients with IIM. Previously, Kang et al reported the test results using IP with the serum of 49 patients with IIM: $6(12.2 \%)$ had anti-ARS, 7 (14.3\%) had anti-Mi-2, 1 (2.0\%) had anti-SRP, 8 (16.3\%) had anti-p155/140 [anti-TIF1 $\gamma$ ] and nine (18.4\%) had anti-p140 [anti-MDA5]. Among MAA, 6 patients had anti-U1 RNP, and 4 had anti-Ro [101]. Recently, Chung et al. [169] presented the result of MSA and MAAs in 67 Korean patients with IIM using immunoblot assay which can detect 15 myositis-related autoantibodies in 2018 Korean College of Rheumatology Annual Conference: 21 (31.3\%) patients had anti-ARS, 14 (20.9\%) had anti-SRP, $14(20.9 \%)$ had anti-MDA5, 8 (11.9\%) had anti-Mi2, 9 (13.3\%) had anti-TIF1 $\gamma, 2$ (3.0\%) had anti-SAE, 32 (47.8\%) had anti-Ro52, and 2 had (3.0\%) anti-Ku. Anti-ARS Abs specificity included anti-Jo-1 (29.2\%), anti-OJ (4.6\%), anti-EJ (6.2\%), anti-PL-7 (3.1\%), and anti-PL-12 (4.6\%).

\section{Implication for patients care}

For classification of IIM, there have been several classification systems, which mainly did not include the presence of autoantibodies. However, with recent discovery of many MSA and MAA, Troyanov et al. [170] proposed the clinicoserologic definition introducing the several subgroups according to the presence of specific MSA [171]. In 2017, European League Against Rheumatism/ American College of Rheumatology classification criteria also included the presence of anti-Jo-1 antibody as one of items for the classification IIM although other antibodies could not investigated for the purpose of classification because of the lack of data [172]. Recently, new classification system based on clinical manifestations and myositis-specific autoantibodies was suggested [173]. Comparing the conventional classification systems, seroclinical classification might designate the patients into the subgroup more appropriately.

As mentioned in the each MSA and MAA section, each autoAb is related to clinical features which have prognostic implication. Patients with anti-ARS and anti-MDA5 showed frequent grave pulmonary manifestation such as AIP or RP-ILD $[37,44,51,81]$ and patients with anti-TIF1 $\gamma$, anti-NXP-2 and anti-HMGCR were often accompanied with malignancy [95,100,102,105,139]. Thus, clinician should be alert to care those IIM patients. The titer of anti-MDA5, anti-SRP and anti-HMGCR can be associated with disease activity $[89,90,127,138]$. The patients with anti-HMGCR may show good treatment response with IVIG $[138,141]$. Considering these research findings, the detection and measurement of MSA and MAA is crucial in patients care.

\section{CONCLUSION}

Various MSA and MAA are found in patients diagnosed with IIM. Based on the MSA and MAA profile, patients can be categorized into specific clinical syndromes, and managed via appropriate treatment strategies for predictable outcomes. With advances in knowledge regarding these autoantibodies and their pathogenic role in IIM, new immunoassays and treatment modalities will become widely available for clinical application in the near future.

\section{ACKNOWLEDGMENTS}

This research was supported by the Basic Science Research Program through the NRF funded by the Ministry of Education (NRF-2018R1D1A1B07043681).

\section{CONFLICT OF INTEREST}

No potential conflict of interest relevant to this article was reported.

\section{REFERENCES}

1. Bohan A, Peter JB. Polymyositis and dermatomyositis 
(first of two parts). N Engl J Med 1975;292:344-7.

2. Bohan A, Peter JB. Polymyositis and dermatomyositis (second of two parts). N Engl J Med 1975;292:403-7.

3. Dalakas MC. Polymyositis, dermatomyositis and inclusion-body myositis. N Engl J Med 1991;325:1487-98.

4. Dalakas MC, Hohlfeld R. Polymyositis and dermatomyositis. Lancet 2003;362:971-82.

5. Dalakas MC. Review: an update on inflammatory and autoimmune myopathies. Neuropathol Appl Neurobiol 2011;37:226-42.

6. Luo YB, Mastaglia FL. Dermatomyositis, polymyositis and immune-mediated necrotising myopathies. Biochim Biophys Acta 2015;1852:622-32.

7. Engel AG, Hohlfeld R. The polymyositis and dermatomyositis complex. In: Engel AG, Franzini-Armstrong C, eds. Myology. New York, McGraw-Hill, 2008, p. 1335-83.

8. Ernste FC, Reed AM. Idiopathic inflammatory myopathies: current trends in pathogenesis, clinical features, and up-to-date treatment recommendations. Mayo Clin Proc 2013;88:83-105.

9. Dalakas MC. Inflammatory muscle diseases. $\mathrm{N}$ Engl J Med 2015;372:1734-47.

10. Huber AM, Lang B, LeBlanc CM, Birdi N, Bolaria RK, Malleson $\mathrm{P}$, et al. Medium- and long-term functional outcomes in a multicenter cohort of children with juvenile dermatomyositis. Arthritis Rheum 2000;43:541-9.

11. Ramanan AV, Feldman BM. Clinical features and outcomes of juvenile dermatomyositis and other childhood onset myositis syndromes. Rheum Dis Clin North Am 2002;28:833-57.

12. McCann LJ, Juggins AD, Maillard SM, Wedderburn LR, Davidson JE, Murray KJ, et al. The Juvenile Dermatomyositis National Registry and Repository (UK and Ireland)--clinical characteristics of children recruited within the first 5 yr. Rheumatology (Oxford) 2006;45: 1255-60.

13. Tan EM. Antinuclear antibodies: diagnostic markers for autoimmune diseases and probes for cell biology. Adv Immunol 1989;44:93-151.

14. Mimori T. Autoantibodies in connective tissue diseases: clinical significance and analysis of target autoantigens. Intern Med 1999;38:523-32.

15. Gunawardena $\mathrm{H}$. The clinical features of myositis-associated autoantibodies: a review. Clin Rev Allergy Immunol 2017;52:45-57.

16. Palterer B, Vitiello G, Carraresi A, Giudizi MG, Cammelli $\mathrm{D}$, Parronchi P. Bench to bedside review of myositis autoantibodies. Clin Mol Allergy 2018;16:5.

17. Targoff IN. Update on myositis-specific and myositis-associated autoantibodies. Curr Opin Rheumatol 2000;12:475-81.

18. McHugh NJ, Tansley SL. Autoantibodies in myositis. Nat Rev Rheumatol 2018;14:290-302.

19. Targoff IN. Autoantibodies in polymyositis. Rheum Dis Clin North Am 1992;18:455-82.

20. Love LA, Leff RL, Fraser DD, Targoff IN, Dalakas M, Plotz $\mathrm{PH}$, et al. A new approach to the classification of idiopathic inflammatory myopathy: myositis-specific autoantibodies define useful homogeneous patient groups. Medicine (Baltimore) 1991;70:360-74.

21. Targoff IN, Miller FW, Medsger TA Jr, Oddis CV.
Classification criteria for the idiopathic inflammatory myopathies. Curr Opin Rheumatol 1997;9:527-35.

22. Satoh M, Tanaka S, Ceribelli A, Calise SJ, Chan EK. A comprehensive overview on myositis-specific antibodies: new and old biomarkers in idiopathic inflammatory myopathy. Clin Rev Allergy Immunol 2017;52:1-19.

23. Targoff IN, Arnett FC. Clinical manifestations in patients with antibody to PL-12 antigen (alanyl-tRNA synthetase). Am J Med 1990;88:241-51.

24. Hirakata M, Suwa A, Nagai S, Kron MA, Trieu EP, Mimori T, et al. Anti-KS: identification of autoantibodies to asparaginyl-transfer RNA synthetase associated with interstitial lung disease. J Immunol 1999;162:2315-20.

25. Nakashima R, Imura Y, Hosono Y, Seto M, Murakami A, Watanabe $\mathrm{K}$, et al. The multicenter study of a new assay for simultaneous detection of multiple anti-aminoacyl-tRNA synthetases in myositis and interstitial pneumonia. PLoS One 2014;9:e85062.

26. Colafrancesco S, Priori R, Valesini G. Inflammatory myopathies and overlap syndromes: Update on histological and serological profile. Best Pract Res Clin Rheumatol 2015;29:810-25.

27. Frank MB, McCubbin V, Trieu E, Wu Y, Isenberg DA, Targoff IN. The association of anti-Ro52 autoantibodies with myositis and scleroderma autoantibodies. J Autoimmun 1999;12:137-42.

28. Mahler M, Miller FW, Fritzler MJ. Idiopathic inflammatory myopathies and the anti-synthetase syndrome: a comprehensive review. Autoimmun Rev 2014; 13:367-71.

29. Nakashima R, Mimori T. Clinical and pathophysiological significance of myositis-specific and myositis-associated autoantibodies. Int J Clin Rheumatol 2010;5:523-36.

30. Witt LJ, Curran JJ, Strek ME. The diagnosis and treatment of antisynthetase syndrome. Clin Pulm Med 2016;23:218-26.

31. Marguerie C, Bunn CC, Beynon HL, Bernstein RM, Hughes JM, So AK, et al. Polymyositis, pulmonary fibrosis and autoantibodies to aminoacyl-tRNA synthetase enzymes. QJ Med 1990;77:1019-38.

32. Arnett FC, Targoff IN, Mimori T, Goldstein R, Warner NB, Reveille JD. Interrelationship of major histocompatibility complex class II alleles and autoantibodies in four ethnic groups with various forms of myositis. Arthritis Rheum 1996;39:1507-18.

33. Bernstein RM, Bunn CC, Hughes GR, Francoeur AM, Mathews MB. Cellular protein and RNA antigens in autoimmune disease. Mol Biol Med 1984;2:105-20.

34. Hirakata M, Mimori T, Akizuki M, Craft J, Hardin JA, Homma M. Autoantibodies to small nuclear and cytoplasmic ribonucleoproteins in Japanese patients with inflammatory muscle disease. Arthritis Rheum 1992;35: 449-56.

35. Friedman AW, Targoff IN, Arnett FC. Interstitial lung disease with autoantibodies against aminoacyl-tRNA synthetases in the absence of clinically apparent myositis. Semin Arthritis Rheum 1996;26:459-67.

36. Yamasaki Y, Yamada H, Nozaki T, Akaogi J, Nichols C, Lyons $\mathrm{R}$, et al. Unusually high frequency of autoantibodies to PL-7 associated with milder muscle disease in Japanese patients with polymyositis/dermatomyositis. 
Arthritis Rheum 2006;54:2004-9.

37. Hamaguchi Y, Fujimoto M, Matsushita T, Kaji K, Komura $\mathrm{K}$, Hasegawa $\mathrm{M}$, et al. Common and distinct clinical features in adult patients with anti-aminoacyl-tRNA synthetase antibodies: heterogeneity within the syndrome. PLoS One 2013;8:e60442.

38. Klein M, Mann H, Pleštilová L, Betteridge Z, McHugh N, Remáková M, et al. Arthritis in idiopathic inflammatory myopathy: clinical features and autoantibody associations. J Rheumatol 2014;41:1133-9.

39. Marie I, Josse S, Decaux O, Dominique S, Diot E, Landron $\mathrm{C}$, et al. Comparison of long-term outcome between anti-Jo1- and anti-PL7/PL12 positive patients with antisynthetase syndrome. Autoimmun Rev 2012;11:739-45.

40. Marie I, Josse S, Decaux O, Diot E, Landron C, Roblot P, et al. Clinical manifestations and outcome of anti-PL7 positive patients with antisynthetase syndrome. Eur J Intern Med 2013;24:474-9.

41. Aggarwal R, Cassidy E, Fertig N, Koontz DC, Lucas M, Ascherman DP, et al. Patients with non-Jo-1 anti-tRNA-synthetase autoantibodies have worse survival than Jo-1 positive patients. Ann Rheum Dis 2014;73: 227-32.

42. Watanabe K, Handa T, Tanizawa K, Hosono Y, Taguchi Y, Noma S, et al. Detection of antisynthetase syndrome in patients with idiopathic interstitial pneumonias. Respir Med 2011;105:1238-47.

43. Schneider F, Yousem SA, Bi D, Gibson KF, Oddis CV, Aggarwal R. Pulmonary pathologic manifestations of anti-glycyl-tRNA synthetase (anti-EJ)-related inflammatory myopathy. J Clin Pathol 2014;67:678-83.

44. Johnson C, Connors GR, Oaks J, Han S, Truong A, Richardson B, et al. Clinical and pathologic differences in interstitial lung disease based on antisynthetase antibody type. Respir Med 2014;108:1542-8.

45. Kalluri M, Sahn SA, Oddis CV, Gharib SL, ChristopherStine L, Danoff SK, et al. Clinical profile of anti-PL-12 autoantibody. Cohort study and review of the literature. Chest 2009;135:1550-6.

46. Rider LG, Miller FW, Targoff IN, Sherry DD, Samayoa E, Lindahl $\mathrm{M}$, et al. A broadened spectrum of juvenile myositis. Myositis-specific autoantibodies in children. Arthritis Rheum 1994;37:1534-8.

47. Feldman BM, Reichlin M, Laxer RM, Targoff IN, Stein LD, Silverman ED. Clinical significance of specific autoantibodies in juvenile dermatomyositis. J Rheumatol 1996;23:1794-7.

48. Wedderburn LR, McHugh NJ, Chinoy H, Cooper RG, Salway F, Ollier WE, et al.; Juvenile Dermatomyositis Research Group (JDRG). HLA class II haplotype and autoantibody associations in children with juvenile dermatomyositis and juvenile dermatomyositis-scleroderma overlap. Rheumatology (Oxford) 2007;46:1786-91.

49. Gunawardena H, Betteridge ZE, McHugh NJ. Myositisspecific autoantibodies: their clinical and pathogenic significance in disease expression. Rheumatology (Oxford) 2009;48:607-12.

50. Targoff IN, Reichlin M. The association between Mi-2 antibodies and dermatomyositis. Arthritis Rheum 1985;28: 796-803.

51. Wolstencroft PW, Fiorentino DF. Dermatomyositis clin- ical and pathological phenotypes associated with myositis-specific autoantibodies. Curr Rheumatol Rep 2018;20:28.

52. Ghirardello A, Zampieri S, Iaccarino L, Tarricone E, Bendo R, Gambari PF, et al. Anti-Mi-2 antibodies. Autoimmunity 2005;38:79-83.

53. Nilasena DS, Trieu EP, Targoff IN. Analysis of the Mi-2 autoantigen of dermatomyositis. Arthritis Rheum 1995;38:123-8.

54. Zhang Y, LeRoy G, Seelig HP, Lane WS, Reinberg D. The dermatomyositis-specific autoantigen $\mathrm{Mi} 2$ is a component of a complex containing histone deacetylase and nucleosome remodeling activities. Cell 1998;95:279-89.

55. Petri MH, Satoh M, Martin-Marquez BT, Vargas-Ramírez $\mathrm{R}$, Jara LJ, Saavedra MA, et al. Implications in the difference of anti-Mi-2 and -p155/140 autoantibody prevalence in two dermatomyositis cohorts from Mexico City and Guadalajara. Arthritis Res Ther 2013;15:R48.

56. Okada S, Weatherhead E, Targoff IN, Wesley R, Miller FW. Global surface ultraviolet radiation intensity may modulate the clinical and immunologic expression of autoimmune muscle disease. Arthritis Rheum 2003;48: 2285-93.

57. Love LA, Weinberg CR, McConnaughey DR, Oddis CV, Medsger TA Jr, Reveille JD, et al. Ultraviolet radiation intensity predicts the relative distribution of dermatomyositis and anti-Mi-2 autoantibodies in women. Arthritis Rheum 2009;60:2499-504.

58. O'Hanlon TP, Carrick DM, Targoff IN, Arnett FC, Reveille JD, Carrington $\mathrm{M}$, et al. Immunogenetic risk and protective factors for the idiopathic inflammatory myopathies: distinct HLA-A, -B, -Cw, -DRB1, and -DQA1 allelic profiles distinguish European American patients with different myositis autoantibodies. Medicine (Baltimore) 2006;85:111-27.

59. O'Hanlon TP, Rider LG, Mamyrova G, Targoff IN, Arnett FC, Reveille JD, et al. HLA polymorphisms in African Americans with idiopathic inflammatory myopathy: allelic profiles distinguish patients with different clinical phenotypes and myositis autoantibodies. Arthritis Rheum 2006;54:3670-81.

60. Shamim EA, Rider LG, Pandey JP, O'Hanlon TP, Jara LJ, Samayoa EA, et al. Differences in idiopathic inflammatory myopathy phenotypes and genotypes between Mesoamerican Mestizos and North American Caucasians: ethnogeographic influences in the genetics and clinical expression of myositis. Arthritis Rheum 2002;46:1885-93.

61. Hamaguchi Y, Kuwana M, Hoshino K, Hasegawa M, Kaji $\mathrm{K}$, Matsushita T, et al. Clinical correlations with dermatomyositis-specific autoantibodies in adult Japanese patients with dermatomyositis: a multicenter cross-sectional study. Arch Dermatol 2011;147:391-8.

62. Hengstman GJ, Vree Egberts WT, Seelig HP, Lundberg IE, Moutsopoulos HM, Doria A, et al. Clinical characteristics of patients with myositis and autoantibodies to different fragments of the Mi-2 beta antigen. Ann Rheum Dis 2006;65:242-5.

63. Reed AM, Crowson CS, Hein M, de Padilla CL, Olazagasti JM, Aggarwal R, et al. Biologic predictors of clinical improvement in rituximab-treated refractory myositis. 
BMC Musculoskelet Disord 2015;16:257.

64. Aggarwal R, Bandos A, Reed AM, Ascherman DP, Barohn RJ, Feldman BM, et al. Predictors of clinical improvement in rituximab-treated refractory adult and juvenile dermatomyositis and adult polymyositis. Arthritis Rheumatol 2014;66:740-9.

65. Betteridge Z, Gunawardena H, North J, Slinn J, McHugh $\mathrm{N}$. Identification of a novel autoantibody directed against small ubiquitin-like modifier activating enzyme in dermatomyositis. Arthritis Rheum 2007;56:3132-7.

66. Tarricone E, Ghirardello A, Rampudda M, Bassi N, Punzi L, Doria A. Anti-SAE antibodies in autoimmune myositis: identification by unlabelled protein immunoprecipitation in an Italian patient cohort. J Immunol Methods 2012;384:128-34.

67. Bodoki L, Nagy-Vincze M, Griger Z, Betteridge Z, Szöllősi L, Dankó K. Four dermatomyositis-specific autoantibodies-anti-TIF1 $\gamma$, anti-NXP2, anti-SAE and anti-MDA5-in adult and juvenile patients with idiopathic inflammatory myopathies in a Hungarian cohort. Autoimmun Rev 2014;13:1211-9.

68. Muro Y, Sugiura K, Akiyama M. Low prevalence of anti-small ubiquitin-like modifier activating enzyme antibodies in dermatomyositis patients. Autoimmunity 2013;46:279-84.

69. Fujimoto M, Matsushita T, Hamaguchi Y, Kaji K, Asano $\mathrm{Y}$, Ogawa F, et al. Autoantibodies to small ubiquitin-like modifier activating enzymes in Japanese patients with dermatomyositis: comparison with a UK Caucasian cohort. Ann Rheum Dis 2013;72:151-3.

70. Ge Y, Lu X, Shu X, Peng Q, Wang G. Clinical characteristics of anti-SAE antibodies in Chinese patients with dermatomyositis in comparison with different patient cohorts. Sci Rep 2017;7:188.

71. Betteridge ZE, Gunawardena H, Chinoy H, North J, Ollier WE, Cooper RG, et al. Clinical and human leucocyte antigen class II haplotype associations of autoantibodies to small ubiquitin-like modifier enzyme, a dermatomyositis-specific autoantigen target, in UK Caucasian adult-onset myositis. Ann Rheum Dis 2009;68:1621-5.

72. Sato S, Hirakata M, Kuwana M, Suwa A, Inada S, Mimori $\mathrm{T}$, et al. Autoantibodies to a 140-kd polypeptide, CADM-140, in Japanese patients with clinically amyopathic dermatomyositis. Arthritis Rheum 2005;52:1571-6.

73. Nakashima R, Imura Y, Kobayashi S, Yukawa N, Yoshifuji H, Nojima T, et al. The RIG-I-like receptor IFIH1/MDA5 is a dermatomyositis-specific autoantigen identified by the anti-CADM-140 antibody. Rheumatology (Oxford) 2010;49:433-40.

74. Cao H, Pan M, Kang Y, Xia Q, Li X, Zhao X, et al. Clinical manifestations of dermatomyositis and clinically amyopathic dermatomyositis patients with positive expression of anti-melanoma differentiation-associated gene 5 antibody. Arthritis Care Res (Hoboken) 2012;64:1602-10.

75. Chen Z, Hu W, Wang Y, Guo Z, Sun L, Kuwana M. Distinct profiles of myositis-specific autoantibodies in Chinese and Japanese patients with polymyositis/ dermatomyositis. Clin Rheumatol 2015;34:1627-31.

76. Hall JC, Casciola-Rosen L, Samedy LA, Werner J, Owoyemi K, Danoff SK, et al. Anti-melanoma differentiation-associated protein 5-associated dermatomyo- sitis: expanding the clinical spectrum. Arthritis Care Res (Hoboken) 2013;65:1307-15.

77. Fiorentino D, Chung L, Zwerner J, Rosen A, CasciolaRosen L. The mucocutaneous and systemic phenotype of dermatomyositis patients with antibodies to MDA5 (CADM-140): a retrospective study. J Am Acad Dermatol 2011;65:25-34.

78. Chen Z, Wang Y, Kuwana M, Xu X, Hu W, Feng X, et al. HLA-DRB1 alleles as genetic risk factors for the development of anti-MDA5 antibodies in patients with dermatomyositis. J Rheumatol 2017;44:1389-93.

79. Lin JM, Zhang YB, Peng QL, Yang HB, Shi JL, Gu ML, et al. Genetic association of HLA-DRB1 multiple polymorphisms with dermatomyositis in Chinese population. HLA 2017;90:354-9.

80. Li L, Wang Q, Wen X, Liu C, Wu C, Yang F, et al. Assessment of anti-MDA5 antibody as a diagnostic biomarker in patients with dermatomyositis-associated interstitial lung disease or rapidly progressive interstitial lung disease. Oncotarget 2017;8:76129-40.

81. Chaisson NF, Paik J, Orbai AM, Casciola-Rosen L, Fiorentino D, Danoff S, et al. A novel dermato-pulmonary syndrome associated with MDA- 5 antibodies: report of 2 cases and review of the literature. Medicine (Baltimore) 2012;91:220-8.

82. Wolstencroft PW, Chung L, Li S, Casciola-Rosen L, Fiorentino DF. Factors associated with clinical remission of skin disease in dermatomyositis. JAMA Dermatol 2018;154:44-51.

83. Tansley SL, Betteridge ZE, Gunawardena H, Jacques TS, Owens CM, Pilkington C, et al. Anti-MDA5 autoantibodies in juvenile dermatomyositis identify a distinct clinical phenotype: a prospective cohort study. Arthritis Res Ther 2014;16:R138.

84. Cabezas-Rodríguez I, Morante-Bolado I, Brandy-García A, Queiro-Silva R, Mozo L, Ballina-García FJ. Anti-MDA5 dermatomyositis mimicking psoriatic arthritis. Reumatol Clin 2018;14:224-6.

85. Gono T, Kawaguchi Y, Hara M, Masuda I, Katsumata Y, Shinozaki M, et al. Increased ferritin predicts development and severity of acute interstitial lung disease as a complication of dermatomyositis. Rheumatology (Oxford) 2010;49:1354-60.

86. Muro Y, Sugiura K, Akiyama M. Limitations of a single-point evaluation of anti-MDA5 antibody, ferritin, and IL-18 in predicting the prognosis of interstitial lung disease with anti-MDA5 antibody-positive dermatomyositis. Clin Rheumatol 2013;32:395-8.

87. Lee LW, Narang NS, Postolova A, Seminara N, Kantor MA. Anti-MDA5-positive dermatomyositis presenting as fever of unknown origin. J Gen Intern Med 2016;31: 1530-6.

88. Chen Z, Cao M, Plana MN, Liang J, Cai H, Kuwana M, et al. Utility of anti-melanoma differentiation-associated gene 5 antibody measurement in identifying patients with dermatomyositis and a high risk for developing rapidly progressive interstitial lung disease: a review of the literature and a meta-analysis. Arthritis Care Res (Hoboken) 2013;65:1316-24.

89. Muro Y, Sugiura K, Hoshino K, Akiyama M. Disappearance of anti-MDA-5 autoantibodies in clinically amyopathic 
$\mathrm{DM} /$ interstitial lung disease during disease remission. Rheumatology (Oxford) 2012;51:800-4.

90. Sato S, Kuwana M, Fujita T, Suzuki Y. Anti-CADM140/MDA5 autoantibody titer correlates with disease activity and predicts disease outcome in patients with dermatomyositis and rapidly progressive interstitial lung disease. Mod Rheumatol 2013;23:496-502.

91. Wang J, Guo G, Chen G, Wu B, Lu L, Bao L. Meta-analysis of the association of dermatomyositis and polymyositis with cancer. Br J Dermatol 2013;169:838-47.

92. Targoff IN, Mamyrova G, Trieu EP, Perurena O, Koneru B, O'Hanlon TP, et al. A novel autoantibody to a 155-kd protein is associated with dermatomyositis. Arthritis Rheum 2006;54:3682-9.

93. Kaji K, Fujimoto M, Hasegawa M, Kondo M, Saito Y, Komura K, et al. Identification of a novel autoantibody reactive with 155 and $140 \mathrm{kDa}$ nuclear proteins in patients with dermatomyositis: an association with malignancy. Rheumatology (Oxford) 2007;46:25-8.

94. Satoh M, Chan JY, Ross SJ, Li Y, Yamasaki Y, Yamada H, et al. Autoantibodies to transcription intermediary factor TIF1 $\beta$ associated with dermatomyositis. Arthritis Res Ther 2012;14:R79.

95. Fujimoto M, Hamaguchi $Y$, Kaji K, Matsushita T, Ichimura $\mathrm{Y}$, Kodera $\mathrm{M}$, et al. Myositis-specific anti-155/140 autoantibodies target transcription intermediary factor 1 family proteins. Arthritis Rheum 2012; 64:513-22.

96. Agricola E, Randall RA, Gaarenstroom T, Dupont S, Hill CS. Recruitment of TIF1 $\gamma$ to chromatin via its PHD finger-bromodomain activates its ubiquitin ligase and transcriptional repressor activities. Mol Cell 2011;43:85-96.

97. Kulkarni A, Oza J, Yao M, Sohail H, Ginjala V, Tomas-Loba A, et al. Tripartite Motif-containing 33 (TRIM33) protein functions in the poly(ADP-ribose) polymerase (PARP)-dependent DNA damage response through interaction with Amplified in Liver Cancer 1 (ALC1) protein. J Biol Chem 2013;288:32357-69.

98. Deakin CT, Yasin SA, Simou S, Arnold KA, Tansley SL, Betteridge $\mathrm{ZE}$, et al. Muscle biopsy findings in combination with myositis-specific autoantibodies aid prediction of outcomes in juvenile dermatomyositis. Arthritis Rheumatol 2016;68:2806-16.

99. Fiorentino DF, Kuo K, Chung L, Zaba L, Li S, Casciola-Rosen L. Distinctive cutaneous and systemic features associated with antitranscriptional intermediary factor-1 $\gamma$ antibodies in adults with dermatomyositis. J Am Acad Dermatol 2015;72:449-55.

100. Fiorentino DF, Chung LS, Christopher-Stine L, Zaba L, Li $\mathrm{S}$, Mammen AL, et al. Most patients with cancer-associated dermatomyositis have antibodies to nuclear matrix protein NXP-2 or transcription intermediary factor 1 $\gamma$. Arthritis Rheum 2013;65:2954-62.

101. Kang EH, Nakashima R, Mimori T, Kim J, Lee YJ, Lee EB, et al. Myositis autoantibodies in Korean patients with inflammatory myositis: anti-140-kDa polypeptide antibody is primarily associated with rapidly progressive interstitial lung disease independent of clinically amyopathic dermatomyositis. BMC Musculoskelet Disord 2010; 11:223.

102. Trallero-Araguás E, Rodrigo-Pendás JÁ, Selva-O'Callaghan
A, Martínez-Gómez X, Bosch X, Labrador-Horrillo M, et al. Usefulness of anti-p155 autoantibody for diagnosing cancer-associated dermatomyositis: a systematic review and meta-analysis. Arthritis Rheum 2012;64:523-32.

103. Targoff IN, Trieu E, Levy-Neto M, Fertig N, Oddis CV. Sera with autoantibodies to the MJ antigen react with NXP2. Arthritis Rheum 2007;56:S787.

104. Kimura Y, Sakai F, Nakano O, Kisaki O, Sugimoto H, Sawamura T, et al. The newly identified human nuclear protein NXP-2 possesses three distinct domains, the nuclear matrix-binding, RNA-binding, and coiled-coil domains. J Biol Chem 2002;277:20611-7.

105. Ichimura Y, Matsushita T, Hamaguchi Y, Kaji K, Hasegawa M, Tanino Y, et al. Anti-NXP2 autoantibodies in adult patients with idiopathic inflammatory myopathies: possible association with malignancy. Ann Rheum Dis 2012;71:710-3.

106. Chinoy H, Betteridge ZE, Gunawardena H, Venkovsky J, Allard SA, Gordon PA, et al. Autoantibodies to the p140 autoantigen NXP-2 in adult dermatomyositis. Am Coll Rheum 2009;60:S304.

107. Valenzuela A, Chung L, Casciola-Rosen L, Fiorentino D. Identification of clinical features and autoantibodies associated with calcinosis in dermatomyositis. JAMA Dermatol 2014;150:724-9.

108. Ceribelli A, Fredi M, Taraborelli M, Cavazzana I, Franceschini F, Quinzanini M, et al. Anti-MJ/NXP-2 autoantibody specificity in a cohort of adult Italian patients with polymyositis/dermatomyositis. Arthritis Res Ther 2012;14:R97.

109. Oddis CV, Fertig N, Goel A, Espada G, Confalone Gregorian M, Maldonado Cocco JA. Clinical and serological characterization of the anti-MJ antibody in childhood myositis. Arthritis Rheum 1997;40:S139.

110. Espada G, Maldonado Cocco JA, Fertig N, Oddis CV. Clinical and serologic characterization of an Argentine pediatric myositis cohort: identification of a novel autoantibody (anti-MJ) to a $142-\mathrm{kDa}$ protein. J Rheumatol 2009;36:2547-51.

111. Gunawardena H, Wedderburn LR, Chinoy H, Betteridge ZE, North J, Ollier WE, et al. Autoantibodies to a 140-kd protein in juvenile dermatomyositis are associated with calcinosis. Arthritis Rheum 2009;60:1807-14.

112. Rogers A, Chung L, Li S, Casciola-Rosen L, Fiorentino DF. Cutaneous and systemic findings associated with nuclear matrix protein 2 antibodies in adult dermatomyositis patients. Arthritis Care Res (Hoboken) 2017;69: 1909-14.

113. Albayda J, Pinal-Fernandez I, Huang W, Parks C, Paik J, Casciola-Rosen L, et al. Antinuclear matrix protein 2 autoantibodies and edema, muscle disease, and malignancy risk in dermatomyositis patients. Arthritis Care Res (Hoboken) 2017;69:1771-6.

114. Reeves WH, Nigam SK, Blobel G. Human autoantibodies reactive with the signal-recognition particle. Proc Natl Acad Sci U S A 1986;83:9507-11.

115. Targoff IN, Johnson AE, Miller FW. Antibody to signal recognition particle in polymyositis. Arthritis Rheum 1990;33:1361-70.

116. Kao AH, Lacomis D, Lucas M, Fertig N, Oddis CV. Anti-signal recognition particle autoantibody in patients 
with and patients without idiopathic inflammatory myopathy. Arthritis Rheum 2004;50:209-15.

117. Hengstman GJ, ter Laak HJ, Vree Egberts WT, Lundberg IE, Moutsopoulos HM, Vencovsky J, et al. Anti-signal recognition particle autoantibodies: marker of a necrotising myopathy. Ann Rheum Dis 2006;65:1635-8.

118. Miller T, Al-Lozi MT, Lopate G, Pestronk A. Myopathy with antibodies to the signal recognition particle: clinical and pathological features. J Neurol Neurosurg Psychiatry 2002;73:420-8.

119. Takada T, Hirakata M, Suwa A, Kaneko Y, Kuwana M, Ishihara T, et al. Clinical and histopathological features of myopathies in Japanese patients with anti-SRP autoantibodies. Mod Rheumatol 2009;19:156-64.

120. Ikeda K, Mori-Yoshimura M, Yamamoto T, Sonoo M, Suzuki S, Kondo Y, et al. Chronic myopathy associated with anti-signal recognition particle antibodies can be misdiagnosed as facioscapulohumeral muscular dystrophy. J Clin Neuromuscul Dis 2016;17:197-206.

121. Pestronk A. Acquired immune and inflammatory myopathies: pathologic classification. Curr Opin Rheumatol 2011;23:595-604.

122. Aggarwal R, Oddis CV, Goudeau D, Fertig N, Metes I, Stephens $\mathrm{C}$, et al. Anti-signal recognition particle autoantibody ELISA validation and clinical associations. Rheumatology (Oxford) 2015;54:1194-9.

123. Suzuki S, Yonekawa T, Kuwana M, Hayashi YK, Okazaki Y, Kawaguchi Y, et al. Clinical and histological findings associated with autoantibodies detected by RNA immunoprecipitation in inflammatory myopathies. J Neuroimmunol 2014;274:202-8.

124. Wang L, Liu L, Hao H, Gao F, Liu X, Wang Z, et al. Myopathy with anti-signal recognition particle antibodies: clinical and histopathological features in Chinese patients. Neuromuscul Disord 2014;24:335-41.

125. Ellis E, Ann Tan J, Lester S, Tucker G, Blumbergs P, Roberts-Thomson P, et al. Necrotizing myopathy: clinicoserologic associations. Muscle Nerve 2012;45:189-94.

126. Togawa R, Tanino Y, Nikaido T, Fukuhara N, Uematsu $\mathrm{M}$, Misa K, et al. Three cases of interstitial pneumonia with anti-signal recognition particle antibody. Allergol Int 2017;66:485-7.

127. Benveniste O, Drouot L, Jouen F, Charuel JL, BlochQueyrat C, Behin A, et al. Correlation of anti-signal recognition particle autoantibody levels with creatine kinase activity in patients with necrotizing myopathy. Arthritis Rheum 2011;63:1961-71.

128. Pinal-Fernandez I, Casal-Dominguez M, Mammen AL. Immune-mediated necrotizing myopathy. Curr Rheumatol Rep 2018;20:21.

129. Christopher-Stine L, Casciola-Rosen LA, Hong G, Chung $\mathrm{T}$, Corse AM, Mammen AL. A novel autoantibody recognizing 200-kd and 100-kd proteins is associated with an immune-mediated necrotizing myopathy. Arthritis Rheum 2010;62:2757-66.

130. Friesen JA, Rodwell VW. The 3-hydroxy-3-methylglutaryl coenzyme-A (HMG-CoA) reductases. Genome Biol 2004;5:248.

131. Osaki Y, Nakagawa Y, Miyahara S, Iwasaki H, Ishii A, Matsuzaka T, et al. Skeletal muscle-specific HMG-CoA reductase knockout mice exhibit rhabdomyolysis: a mod- el for statin-induced myopathy. Biochem Biophys Res Commun 2015;466:536-40.

132. Limaye V, Bundell C, Hollingsworth P, Rojana-Udomsart A, Mastaglia F, Blumbergs $P$, et al. Clinical and genetic associations of autoantibodies to 3-hydroxy-3-methyl-glutaryl-coenzyme a reductase in patients with immune-mediated myositis and necrotizing myopathy. Muscle Nerve 2015;52:196-203.

133. Mammen AL, Gaudet D, Brisson D, Christopher-Stine L, Lloyd TE, Leffell MS, et al. Increased frequency of DRB1*11:01 in anti-hydroxymethylglutaryl-coenzyme A reductase-associated autoimmune myopathy. Arthritis Care Res (Hoboken) 2012;64:1233-7.

134. Mammen AL, Chung T, Christopher-Stine L, Rosen P, Rosen A, Doering KR, et al. Autoantibodies against 3-hydroxy-3-methylglutaryl-coenzyme A reductase in patients with statin-associated autoimmune myopathy. Arthritis Rheum 2011;63:713-21.

135. Allenbach Y, Drouot L, Rigolet A, Charuel JL, Jouen F, Romero NB, et al. Anti-HMGCR autoantibodies in European patients with autoimmune necrotizing myopathies: inconstant exposure to statin. Medicine (Baltimore) 2014;93:150-7.

136. Musset L, Allenbach Y, Benveniste O, Boyer O, Bossuyt $\mathrm{X}$, Bentow $\mathrm{C}$, et al. Anti-HMGCR antibodies as a biomarker for immune-mediated necrotizing myopathies: a history of statins and experience from a large international multi-center study. Autoimmun Rev 2016;15: 983-93.

137. Ge Y, Lu X, Peng Q, Shu X, Wang G. Clinical characteristics of anti-3-hydroxy-3-methylglutaryl coenzyme a reductase antibodies in Chinese patients with idiopathic inflammatory myopathies. PLoS One 2015;10:e0141616.

138. Werner JL, Christopher-Stine L, Ghazarian SR, Pak KS, Kus JE, Daya NR, et al. Antibody levels correlate with creatine kinase levels and strength in anti-3-hydroxy-3methylglutaryl-coenzyme A reductase-associated autoimmune myopathy. Arthritis Rheum 2012;64:4087-93.

139. Watanabe Y, Uruha A, Suzuki S, Nakahara J, Hamanaka $\mathrm{K}$, Takayama $\mathrm{K}$, et al. Clinical features and prognosis in anti-SRP and anti-HMGCR necrotising myopathy. J Neurol Neurosurg Psychiatry 2016;87:1038-44.

140. Allenbach $\mathrm{Y}$, Keraen J, Bouvier AM, Jooste V, Champtiaux N, Hervier B, et al. High risk of cancer in autoimmune necrotizing myopathies: usefulness of myositis specific antibody. Brain 2016;139:2131-5.

141. Mammen AL, Tiniakou E. Intravenous immune globulin for statin-triggered autoimmune myopathy. N Engl J Med 2015;373:1680-2.

142. Tiniakou E, Pinal-Fernandez I, Lloyd TE, Albayda J, Paik J, Werner JL, et al. More severe disease and slower recovery in younger patients with anti-3-hydroxy-3-methylglutaryl-coenzyme A reductase-associated autoimmune myopathy. Rheumatology (Oxford) 2017;56:787-94.

143. Tansley SL, Betteridge ZE, Simou S, Jacques TS, Pilkington C, Wood M, et al.; Juvenile Dermatomyositis Research Group. Anti-HMGCR autoantibodies in juvenile idiopathic inflammatory myopathies identify a rare but clinically important subset of patients. J Rheumatol 2017;44:488-92.

144. Wolfe JF, Adelstein E, Sharp GC. Antinuclear antibody 
with distinct specificity for polymyositis. J Clin Invest 1977;59:176-8.

145. Reichlin M, Maddison PJ, Targoff I, Bunch T, Arnett F, Sharp G, et al. Antibodies to a nuclear/nucleolar antigen in patients with polymyositis overlap syndromes. J Clin Immunol 1984;4:40-4.

146. Treadwell EL, Alspaugh MA, Wolfe JF, Sharp GC. Clinical relevance of PM-1 antibody and physiochemical characterization of PM-1 antigen. J Rheumatol 1984;11:658-62.

147. Alderuccio F, Chan EK, Tan EM. Molecular characterization of an autoantigen of PM-Scl in the polymyositis/scleroderma overlap syndrome: a unique and complete human cDNA encoding an apparent $75-\mathrm{kD}$ acidic protein of the nucleolar complex. J Exp Med 1991;173:941-52.

148. Blüthner M, Bautz FA. Cloning and characterization of the cDNA coding for a polymyositis-scleroderma overlap syndrome-related nucleolar 100-kD protein. J Exp Med 1992; 176:973-80

149. Ge Q, Frank MB, O'Brien C, Targoff IN. Cloning of a complementary DNA coding for the 100-kD antigenic protein of the PM-Scl autoantigen. J Clin Invest 1992;90:559-70.

150. Lega JC, Fabien N, Reynaud Q, Durieu I, Durupt S, Dutertre $\mathrm{M}$, et al. The clinical phenotype associated with myositis-specific and associated autoantibodies: a meta-analysis revisiting the so-called antisynthetase syndrome. Autoimmun Rev 2014;13:883-91.

151. Brouwer R, Hengstman GJ, Vree Egberts W, Ehrfeld H, Bozic B, Ghirardello A, et al. Autoantibody profiles in the sera of European patients with myositis. Ann Rheum Dis 2001;60:116-23.

152. Kuwana M, Kaburaki J, Okano Y, Tojo T, Homma M. Clinical and prognostic associations based on serum antinuclear antibodies in Japanese patients with systemic sclerosis. Arthritis Rheum 1994;37:75-83.

153. Aguila LA, Lopes MR, Pretti FZ, Sampaio-Barros PD, Carlos de Souza FH, Borba EF, et al. Clinical and laboratory features of overlap syndromes of idiopathic inflammatory myopathies associated with systemic lupus erythematosus, systemic sclerosis, or rheumatoid arthritis. Clin Rheumatol 2014;33:1093-8.

154. Ho KT, Reveille JD. The clinical relevance of autoantibodies in scleroderma. Arthritis Res Ther 2003;5:80-93.

155. Marguerie C, Bunn CC, Copier J, Bernstein RM, Gilroy $\mathrm{JM}$, Black CM, et al. The clinical and immunogenetic features of patients with autoantibodies to the nucleolar antigen PM-Scl. Medicine (Baltimore) 1992;71:327-36.

156. Jablonska S, Blaszyk M. Scleromyositis (scleroderma/polimyositis overlap) is an entity. J Eur Acad Dermatol Venereol 2004;18:265-6.

157. Mattioli M, Reichlin M. Characterization of a soluble nuclear ribonucleoprotein antigen reactive with SLE sera. J Immunol 1971;107:1281-90.

158. Dima A, Jurcut C, Baicus C. The impact of anti-U1-RNP positivity: systemic lupus erythematosus versus mixed connective tissue disease. Rheumatol Int 2018;38: 1169-78.

159. Migliorini P, Baldini C, Rocchi V, Bombardieri S. Anti-Sm and anti-RNP antibodies. Autoimmunity 2005;38:47-54.
160. Lundberg I, Nennesmo I, Hedfors E. A clinical, serological, and histopathological study of myositis patients with and without anti-RNP antibodies. Semin Arthritis Rheum 1992;22:127-38.

161. Coppo P, Clauvel JP, Bengoufa D, Oksenhendler E, Lacroix C, Lassoued K. Inflammatory myositis associated with anti-U1-small nuclear ribonucleoprotein antibodies: a subset of myositis associated with a favourable outcome. Rheumatology (Oxford) 2002;41:1040-6.

162. Franceschini F, Cavazzana I. Anti-Ro/SSA and La/SSB antibodies. Autoimmunity 2005;38:55-63.

163. Schulte-Pelkum J, Fritzler M, Mahler M. Latest update on the Ro/SS-A autoantibody system. Autoimmun Rev 2009;8:632-7.

164. Yamasaki Y, Satoh M, Mizushima M, Okazaki T, Nagafuchi H, Ooka S, et al. Clinical subsets associated with different anti-aminoacyl transfer RNA synthetase antibodies and their association with coexisting anti-Ro52. Mod Rheumatol 2016;26:403-9.

165. Marie I, Hatron PY, Dominique S, Cherin P, Mouthon L, Menard JF, et al. Short-term and long-term outcome of anti-Jo1-positive patients with anti-Ro52 antibody. Semin Arthritis Rheum 2012;41:890-9.

166. Frank MB, McCubbin V, Trieu E, Wu Y, Isenberg DA, Targoff IN. The association of anti-Ro52 autoantibodies with myositis and scleroderma autoantibodies. J Autoimmun 1999;12:137-42.

167. Mimori T, Akizuki M, Yamagata H, Inada S, Yoshida S, Homma M. Characterization of a high molecular weight acidic nuclear protein recognized by autoantibodies in sera from patients with polymyositis-scleroderma overlap. J Clin Invest 1981;68:611-20.

168. Belizna C, Henrion D, Beucher A, Lavigne C, Ghaali A, Lévesque $\mathrm{H}$. Anti-Ku antibodies: clinical, genetic and diagnostic insights. Autoimmun Rev 2010;9:691-4.

169. Chung SW, Hong S, Yoo IS, Yoo S, Kim JH, Kang SW, et al. Reclassifying of adult autoimmune myositis in Korean patients. Paper presented at: 38th KCR Annual Scientific Meeting and the 12th International Symposium; 2018 May 18-19; Seoul, Korea. p. S194.

170. Troyanov Y, Targoff IN, Tremblay JL, Goulet JR, Raymond Y, Senécal JL. Novel classification of idiopathic inflammatory myopathies based on overlap syndrome features and autoantibodies: analysis of 100 French Canadian patients. Medicine (Baltimore) 2005;84:231-49.

171. Senécal JL, Raynauld JP, Troyanov Y. Editorial: a new classification of adult autoimmune myositis. Arthritis Rheumatol 2017;69:878-84.

172. Lundberg IE, Tjärnlund A, Bottai $M$, Werth VP, Pilkington C, de Visser M, et al. 2017 European League Against Rheumatism/American College of Rheumatology classification criteria for adult and juvenile idiopathic inflammatory myopathies and their major subgroups. Arthritis Rheumatol 2017;69:2271-82.

173. Mariampillai K, Granger B, Amelin D, Guiguet M, Hachulla E, Maurier F, et al. Development of a new classification system for idiopathic inflammatory myopathies based on clinical manifestations and myositis-specific autoantibodies. JAMA Neurol 2018;75:1528-37. 